\title{
Knowledge and Attitude of Female Sex Workers in Offering Condoms to Sex Customers in Medan
}

\author{
Dhani Syahputra Bukit \\ Public Health Faculty University of Sumatera Utara Department Health Promotion, Indonesia \\ dhani.bukit@gmail.com
}

\begin{abstract}
The high prevalence of HIV-AIDS in Medan North Sumatra as many as 3,780 cases and there has been a decrease in condom use $(\mathbf{8 6 \%})$ to $(51.5 \%)$ in 2011 . In order to determine the cause of the condition it needs to be known description of female sex workers (FWS) behavior in offering condom for customers during sexual intercourse. The aim of this study was to explore in depth information about the behavior of female sex workers in offering a condom for customers during sexual intercouse in Medan Qualitative methods had been used in this study. The research data obtained by conducting indepth interviews to 12 female sex workers and 8 key informants consisting of National AIDS Commission, Department of Health, Office of Women's Empowerment and NGO in Medan, pimps and customers of sex. The results showed that female sex workers' knowledge and attitude about HIV-AIDS and condoms is high. Female sex workers behavior in offering condoms to customers is good but the bargaining power of female sex workers as well as the ability to negotiate in offering condom is non optimal, therefore condom use still inconsistent and low, so that it's required the increasing number of effort of comprehensive condom promotion both to the female sex workers, customers and related parties.
\end{abstract}

Keywords - Female Sex Workers (FSW), Offers Condoms, Knowledge and Attitude, Behaviour

\section{INTRODUCTION}

Acquired immune deficiency syndrome (AIDS) is a collection of symptoms caused by the human immunodeficiency virus (HIV) that damages the human immune system so that the immune system is weakened and easy to get infectious disease (KPAN, 2010). UNAIDS (united nations program on HIV-AIDS), a WHO agency that handles AIDS estimates that as many as 40 millions people are infected by HIV worldwide, and Indonesia is one of countries in Asia with the fastest growing epidemic[1]

Transmission of HIV in Indonesia today still continues with a worrying increase, in which in 2012 , there were 27,197 new cases, with 21,511 of them are cases of HIV and the remaining is positive for AIDS, whereas until March 2013, cumulative cases of HIV-AIDS reached 143,899 cases consisting of $98,390 \mathrm{HIV}$ and 45,499 AIDS by
8,235 deaths. The highest HIV transmission is through sexual intercourse at risk (men do not wear a condom) to heterosexual (52.8\%), sharing needles in drug abusers (10.3\%), and Men Like Male Sex $(7.7 \%)[3]$.

Condom is one of things that can be worn and used by commercial sex workers, both men and women and can be used also by customers that serves to prevent or reduce the transmission of disease. Results explains that the rate of condom use among indirect female sex workers working in entertainment venues such as nightclubs, massage parlors, discotheques, cafes, karaoke bars or bars is lower than the rate of condom use by sex workers in brothels or often called as direct female sex workers [13].

The bargaining power in negotiating condom use is influenced by several factors, they are knowledge, negotiating skills, attitudes toward condoms, consistency of women, perceptions of health, the temperamental nature of the couple, courage and self-confidence, the resistance of the couple, competition with peers, and economics. This bargaining power will make female sex workers consistent to use condoms [4]. The bargaining power of condom use is influenced by several factors. The multifactor analysis of the empowerment of female sex workers and HIV prevention in Botswana explains that the decision to use condoms is significantly related to the education and empowerment of women [6]

Integrated Biological and Behavioural Survey Report (IBBS) explains the number of female sex workers indirectly offering condoms to their customers in Indonesia was $74 \%$ and those using condoms to customers was only $66 \%$, while in Medan, the number of female sex workers indirectly offering condoms to customers was $91 \%$ 
and those using condoms was $86 \%$. Then from 2011 IBBS report, the number of female sex workers in Medan that use a condom during the last sexual intercourse was $51.5 \%$ [7].

Based on the explanation above, it needs to do qualitative research to gain in-depth information about the behavior of female sex workers in offering customers a condom during sexual intercourse in Medan.

\section{STUDY METHOD}

The study was conducted in Medan on March and April 2014 using a qualitative research method with Rapid Assessment Procedure (RAP) approach. Data was collected by in-depth interviews to 12 female sex workers consisting of 4 female sex workers in spa, 4 female sex workers in hotel, 4 female sex workers in street, 1 Department of Health, 1 KPA of Medan, 1 Department of Women Empowerment Medan, $1 \mathrm{H} 2 \mathrm{O}$ NGO, 2 pimps and 2 customers. Data analysis used is content analysis. Researcher performed data reduction by selecting, coding, classifying and separating things that are not needed in this study. Then, the researcher presented data in the matrix by categories to make it easier to read and draw conclusions from data that has been collected to be used as a complete study results.

\section{RESULT}

Female sex worker informants in this study are twelve people consisted of female sex workers in spa, female sex workers in hotel and female sex workers in street

TABLE I

CHARACTERISTICS OF INFORMAN

\begin{tabular}{|c|c|c|c|c|c|}
\hline No & Initial & $\begin{array}{c}\text { Age } \\
\text { (years } \\
\text { old) }\end{array}$ & Education & $\begin{array}{c}\text { Duration } \\
\text { of Work } \\
\text { (year) }\end{array}$ & Hotspot \\
\hline 1 & WT(o) & 26 & $\begin{array}{r}\text { Elementary } \\
\text { School }\end{array}$ & 8 months & Spa \\
\hline 2 & YN(o) & 28 & $\begin{array}{r}\text { Elementary } \\
\text { School }\end{array}$ & 2 & Spa \\
\hline 3 & MW(o) & 39 & $\begin{array}{c}\text { Junior High } \\
\text { School }\end{array}$ & 3 & Spa \\
\hline 4 & SR(o) & 24 & Senior High & 1 & Spa \\
\hline
\end{tabular}

\begin{tabular}{|c|c|c|c|c|c|}
\hline 5 & SM(h) & 31 & $\begin{array}{c}\text { Elementary } \\
\text { School }\end{array}$ & 8 & Inn \\
\hline 6 & SS(h) & 36 & $\begin{array}{c}\text { Elementary } \\
\text { School }\end{array}$ & 3 & Inn \\
\hline 7 & WD(h) & 31 & $\begin{array}{c}\text { Junior High } \\
\text { School }\end{array}$ & 3 & Inn \\
\hline 8 & SU(h) & 46 & $\begin{array}{c}\text { Elementary } \\
\text { School }\end{array}$ & 11 & Inn \\
\hline 9 & LN(j) & 23 & $\begin{array}{c}\text { Senior High } \\
\text { School }\end{array}$ & 2 & Street \\
\hline 10 & GM(j) & 24 & $\begin{array}{c}\text { Junior High } \\
\text { School }\end{array}$ & 1 & Street \\
\hline 11 & AY(j) & 33 & $\begin{array}{c}\text { Senior High } \\
\text { School }\end{array}$ & 1 & Street \\
\hline & AN(j) & 32 & $\begin{array}{c}\text { Elementary } \\
\text { School }\end{array}$ & 4 & Street \\
\hline
\end{tabular}

A Female sex workers offer condoms to customers, but they are also inconsistent in using condoms to customers because many customers do not want to use it with the reasons of being disturbed and reduce the pleasure in sexual intercourse. Then, the offer of using condom is also inconsistent because the customer is the female sex worker's customer itself. Female sex workers already have partners, they are generally comfortable with their customers due to the emergence of a sense of trust with their partners. Confidence that the customer is healthy and safe from disease, moreover, there would appear compassion and love towards the customer so that the process offering the condoms will certainly not be made by female sex workers. In general, female sex workers have regular customers so the offer of using condom is reduced and the consistency pf the use will also be reduced, in accordance with the following statement:

"Men usually feel uncomfortable when using condom, we told them that by using condom, it will make sex lasts longer, more comfortable, safer for family and others," (SRo) 
Most female sex workers understand about HIVAIDS, related to transmission, prevention and the dangers they pose. This study gains female sex workers' knowledge about condoms related to the benefits of condoms and how to use condoms correctly, according to the statement.

"Usually, we use condom in sexual intercourse to prevent the disease.." (SMh).

"It can be from the sexual intercourse, sharing needles, and blood transfusion.. Condom can be used to prevent pregnancy, prevent disease such as HIV, IMS..” (SMh)

The informant explained that by using condom can prevent the transmission of HIV-AIDS but most informants could not explain rules and how to use condoms properly. The informant also explained by sexual intercourse and through needles can transmit HIV and for the prevention of HIV-AIDS. But there are also female sex workers that have misconceptions about HIV-AIDS prevention by drinking or injecting antibiotics can prevent HIVAIDS. This study obtains information that those most at risk of HIV AIDS are customers and female sex workers.

Most female sex workers have a good attitude towards HIV transmission and offering of condoms. A good attitude is also seen how they explained that the transmission of HIV-AIDS can be fatal for themselves and the customers. Then the attitude of female sex workers to offer condoms to customers is good and assume that offerring condoms to the customer is not difficult and does not make the number of female sex worker customers are decreased, in accordance with the following statement:

"not like that, if it is for safety, why we feel it wastes time or makes difficult, it makes both costumers and us healthy. We need money but the health is also important..." (SMh)

Female sex workers' attitude in suggesting condom is the most convenient tool in preventing HIV-AIDS is optimal. Female sex workers' attitude in offering condoms to customers is optimal and in line with their knowledge. All female sex workers agree that by offering condoms to the customers make them protected from HIV-AIDS disease, not difficult and do not make the number of customers decreased.

\section{IV.DISCUSSION}

At the end, inconsistency of offering and using condoms due to the possibility of bargaining and negotiation skills of female sex workers to low condom use. Knowledge about sexually transmitted infections and condoms is essential before one decides to perform certain health measures, in this case is by wearing a condom during sexual intercourse. However, this behavior may not happen if the knowledge obtained is not strong enough to motivate a person to do the behavior. Another thing is the knowledge level has just been at the stage of understanding, has not reached the stage of application, analysis, synthesis and evaluation [9]. Knowledge about appropriate transmission of HIV is very important for risk groups and as one of the basic capital so that they want to reduce risk behavior or the use of prevention tools such as condoms and sterile injecting equipment [8].

Knowledge about sexually transmitted infections and condoms is essential before someone decides to perform certain health measures, in this case is to wear a condom during sexual intercourse. However, this may not happen if the knowledge obtained is not strong enough to motivate a person to do that. The other thing is the level of knowledge has just been at the stage of understanding, not reached the stage of application, analysis, synthesis and evaluation [9]. Appropriate knowledge about how HIV transmits is really important for risk groups and it is one of the basics so that they want to reduce risk behavior or use prevention tools such as condoms and sterile injecting equipment [7].

Results of the another research statistically showed a significant relationship between knowledge of HIV-AIDS with the behavior requiring the use of condoms to customers [10], [2]. Study on knowledge was the result there is a significant relationship between female sex workers knowledge and decision in offering safe sex [11]. The study describes female sex workers knowledge related to female sex workers behavior in useing and offering condoms to customers [4]. 
Informants have a good attitude towards HIV transmission and offering condoms. A good attitude is also seen from the way female sex workers explained that the transmission of HIV-AIDS can be fatal for female sex workers and the customers. Then the attitude of female sex workers to offer condoms to customers is good and assume that offering condoms to the customer is not difficult and does not make the number of customers decreased. Female sex workers attitude in suggesting condom as the most convenient tool in preventing HIV-AIDS is optimal. Female sex workers attitude in offering condoms to customers has been optimized and in line with their knowledge. All female sex workers agreed that by offering customers a condom avoids HIV-AIDS disease, not difficult and does not make the number of customers decreased.

Attitude is a tendency of learning outcomes to behave influenced by the situation and the environment. Attitude is potential for someone to change the behavior of the mind, feelings and concerns. Attitude is an evaluative statement, emotional feelings and tendencies made by humans against oneself, another person, object or issues of an object in form of a statement to support or against an object. Attitude is a closed thing as a collection of symptoms in response to a stimulus that involves the thoughts, feelings and concerns [9].

Good attitude towards the benefits of condom use is expected to increase the motivation of female sex workers to always use condoms consistently. This attitude is very important as a trigger in increasing their motivation to always use a condom during sexual intercourse. Motivation is the inner strength to improve the consistency of condom use. Attitudes are formed from their knowledge and experience. Knowledge which only knows without a true understanding can lead to the formation of the wrong attitude. Attitudes are often influenced by the myths that exist in society. The study describes that attitude has the relationship with the use of condoms to customers [13]. These results are in accordance with the opinion of Green and Kreuter which states that attitude is a factor to facilitate behavioral change [5].

\section{CONCLUSION}

Based on this study, it can be concluded that female sex workers have a good knowledge and attitudes toward condom deals. FWS behavior in offering condoms to customers has been good, but almost all female sex workers are inconsistent in the use of condoms to customers because many customers do not want to use it with the reasons of being disturbed and reducing the pleasure in sexual intercourse. Female sex workers bargaining power and low ability to negotiate cause supply and use of condoms is not optimal.

\section{SUGGESTIONS}

Based Some suggestions that can be given from this study are Medan City Health Department are expected to maximize existing condom promotion program by disseminating to female sex workers, pimps and the community so that it will be more targeted and increase awareness of FSW, pimps, and the public on the importance of joint health. Medan KPA and NGO are expected to increase street female sex workers outreach related to the importance of condoms for the increased understanding so the bargaining position of street female sex workers becomes better and provides understanding of the importance of condoms to pimps thus they are more concerned about female sex workers health generally in the prevention of sexually transmitted infections and HIV-AIDS.

\section{REFERENCES}

[1] UNAIDS, WHO. (2008). Current Information about Aids Epidemic December 2008. Joint United Nations Programme on HIV/ AIDS (UNAIDS) and World Health Organizations (WHO). Switzerland

[2] National AIDS Tackling Committee (2010) National Action Strategy and Plan for HIV and AIDS on 2010 - 2014. Jakarta.

[3] Ministry of Health of Republic of Indonesia. (2013). Development Report of HIV/AIDS in Indonesia, Quarterly IV of 2012. Jakarta. Directorate of PP \& PL

[4] East L, et all (2011). Condom negotiation: Experiences of sexually active young women. Journal of Advanced Nursing, Jan; 67 (1): 77-85

[5] Green, Lawrence W and Marshall W Kreuter. Health Promotion Plannin: An Educational and Environmental Approach. United States of America: Mayfield Publishing Company, 1991.

[6] Department of Health of Republic of Indonesia (2009). Integrated Biological and Behavioural Survey Report of 2007. Directorate of PP \& PL. Jakarta

[7] Ministry of Health of Republic of Indonesia (2012). Integrated Biological and Behavioural Survey Report of 2007. Directorate of PP \& PL. Jakarta.

[8] Notoatmodjo, Soekidjo. (2005). Health Education and Behavior. Jakarta: Rineka Cipta

[9] Dona, Amalia. (2011). Relationship of Characteristic and Knowledge About HIV/AIDS in Direct Female Sex Workers towards Behavior Requiring Condom Use to the Customers in Sintai Localization in 
Teluk Pandan, Batam at 2011. Thesis of Faculty of Public Health UI. Depok

[10] Popoola, B.I. (2009). Sex-negotiation strategies and safer-sex practices among married women in South-Western Nigeria. Nigeria, Educationa Foundations \& Counselling, Faculty of Education, Obafemi Awolowo University, Vol. 24, Nos. 3-4, August-November 2009, 261-270

[11] Silalahi, Roselly Elviyanti. (2008). Predisposition Factor Influence, Supporting and Strengthening to the Commercial Sex Workers (CSW) Measures in Using Condoms For HIV/AIDS Prevention in Teleju Localization, Pekanbaru of 2008. Thesis: USU Repository.
[12] Sutri A.S (2012), Predisposition Relationship Factors, Supporting And Strengthening With Condom Use to CSW For Hiv-Aids Prevention in Serdang Bedagai, Jurnal Precure Vol 1. Epi Treat Unit-USU

[13] Lokollo, F. Y. (2009). The Case Study of Behavior Female Sex Worker not Direct in Prevention of HIV and AIDS in Pub \& Karaoke, Cafes, and Discotik in the City of Semarang 